\title{
Telemedicine in the Midst of the COVID-19 Crisis: A Case Study in Government and Healthcare Agility
}

\author{
Immanuel Azaad Moonesar RD ${ }^{1 *}$, Melodena Stephens ${ }^{2}$, Kulaithem Saif Al Mazrouei ${ }^{3}$, Dorcus \\ Kiwanuka Henriksson ${ }^{4}$ and Vladimir Sergeevich Gordeev ${ }^{5,6}$
}

\begin{abstract}
${ }^{1}$ Associate Professor, Health Administration and Policy, Mohammed Bin Rashid School of Government, Dubai, UAE
2Professor of Innovation Management, Mohammed Bin Rashid School of Government, Dubai, UAE

${ }^{3}$ Director of Health Center Department, Primary Health Care DHA Dubai Health Authority, UAE

${ }^{4}$ Senior Policy Advisor for Health and SRHR, Swedish International Development Cooperation Agency, Stockholm, Sweden

${ }^{5}$ Senior Health Economist, Institute of Population Health Sciences, Queen Mary University of London, London, UK

${ }^{6}$ Assistant Professor, Department of Infectious Disease Epidemiology, London School of Hygiene \& Tropical Medicine, London, UK
\end{abstract}

\section{Introduction}

In the aftermath of the coronavirus COVID-19 pandemic, nations will have to rethink their healthcare systems and health care delivery in the face of this global health calamity. Hospitals and clinics are battling the rising COVID-19 problem, which puts our healthcare workers in danger of infection and death. As of mid-January 2021, there have been about 90 million verified cases of COVID-19 and nearly 1.93 million COVID-19-related fatalities throughout the world [1]. Many nations have adopted the 2018 WHO Guide on managing epidemics [2] to combat the pandemic crisis. Preparedness, reaction, and recovery are all aspects of crisis management (Figure 1) [3]. Despite the fact that the book was written in 2018 and many nations had already dealt with epidemics, the pandemic nonetheless snuck up on many healthcare systems. Coordination between the United States and other countries was a significant issue. Different methods were used to prevent the virus from spreading.

It is expected that more than 100 nations would have implemented a variety of measures to prevent the spread of the virus by the end of March or the beginning of April 2020 [4]. Many non-emergency health services were halted due to a shortage of personnel, resources, ICU beds, and critical care equipment at healthcare facilities. By declaring, WHO has acknowledged this "vaccine-preventable and curable illnesses, as well as direct mortality from an epidemic, rise considerably when health services are overburdened. A delicate balance must be struck between the urgent need to react to COVID-19 immediately and the need for strategic planning and coordinated effort to preserve the supply of basic health services, therefore reducing the likelihood of a systemic breakdown [5]." Outcome services (70 percent), non-communicable disease diagnosis (69 percent), family planning and contraception (68 percent), mental health treatment (61 percent), and antenatal care (56 percent) were the most frequently disrupted services in a survey conducted in May-July, 2020 from 105 countries, according to a press release [6].

The stoppage or inability to physically obtain healthcare affected more than just patients. Financial losses were suffered by medical facilities and professionals as well. Hospitals in the United States lost US\$200 billion in only four months, with 80 percent of it coming from elective treatments [7]. During the months of February and April, 1.5 million health care employees were laid off as a result of the rising costs. In December 2020, the second wave of lockdowns occurred despite a 12-month preparation period for the healthcare sector [8]. The massive increase in cases and deaths caught the health system off guard, highlighting once again the government's inability to respond quickly to health care management issues.

\section{Government's Role in Healthcare-A review}

The capacity of a government to provide its citizens with high-quality, affordable healthcare is a critical component of its worth to the public. In many nations, healthcare spending

*Corresponding author: Immanuel Azaad Moonesar RD, Associate Professor- Health Administration and Policy, Mohammed Bin Rashid School of Government, Dubai, UAE

Accepted: February 10, 2022

Published online: February 12, 2022

Citation: Moonesar IA, Stephens M, Mazrouei KSA, et al. (2022) Telemedicine in the Midst of the COVID-19 Crisis: A Case Study in Government and Healthcare Agility. J Healthcare 5(1):117125 

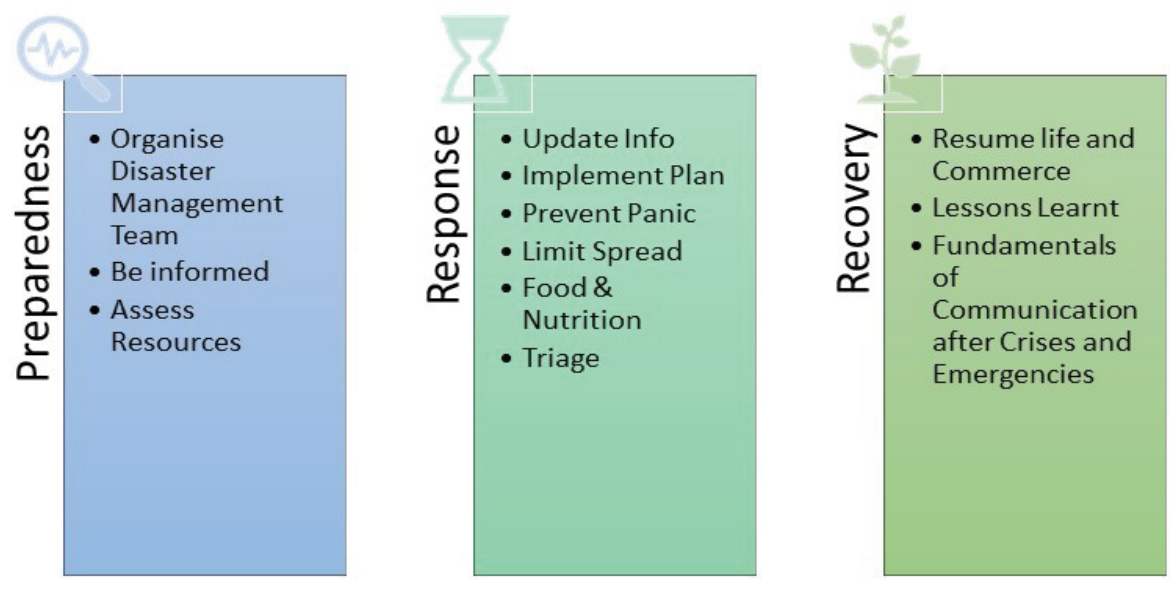

Figure 1: Managing epidemics: Systematic approaches and leadership thinking [3].

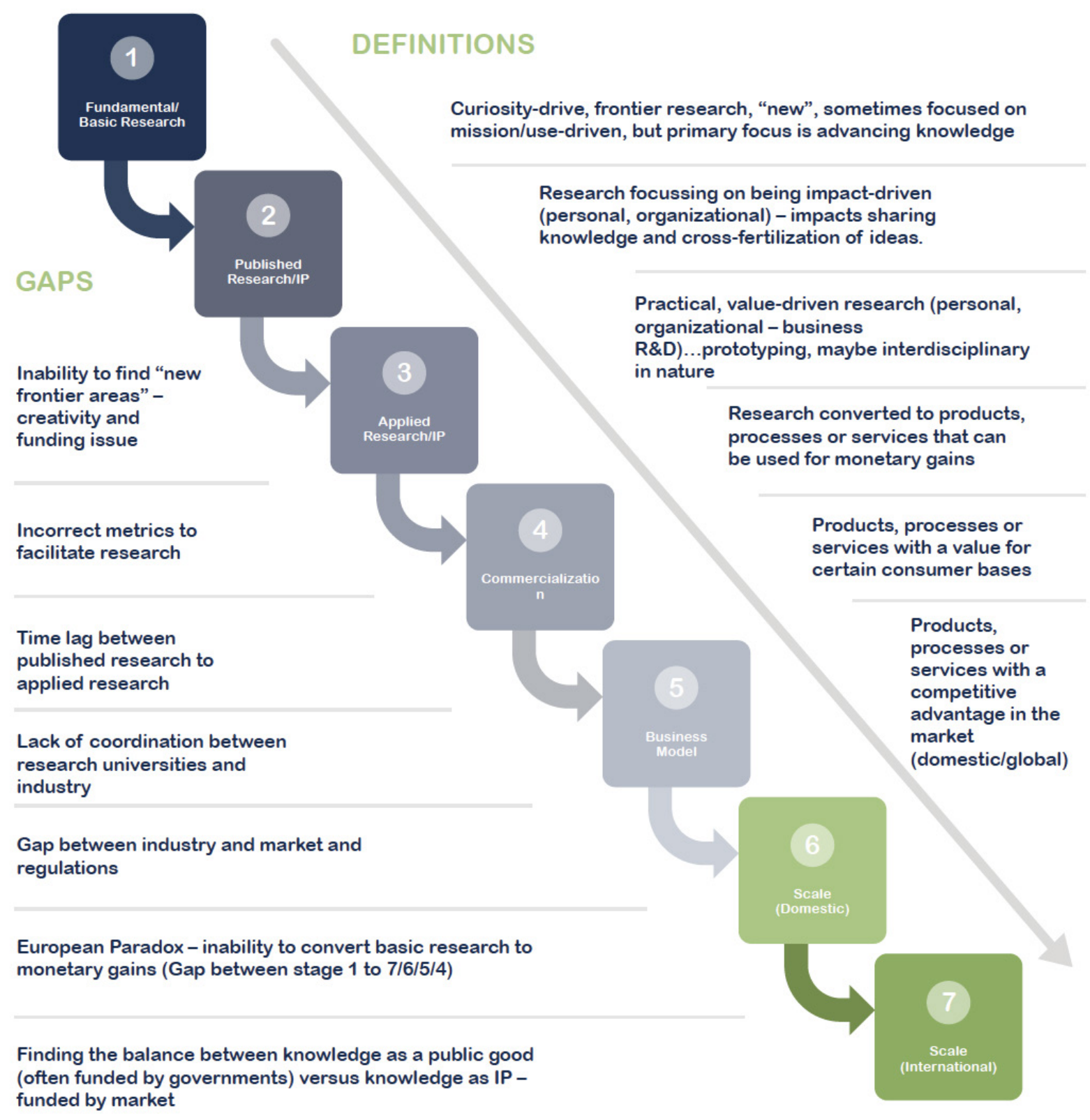

Figure 2: Innovation continuum [12]. 
growth is outpacing GDP growth, and this trend is expected to worsen as the population ages [9]. A government's ability to provide health care depends on a number of things.

\section{New innovations in a regulated environment}

Achieving an agile healthcare system is difficult in today's complicated regulatory and stakeholder environment. In terms of new health care advances, there is a large time gap between research at the cutting edge and its commercialization (Figure 2). There is a moral quandary surrounding the use of embryonic stem cells in the development of mRNA vaccines, which dates back to the 1990s [10]. In the battle against COVID, mRNA vaccines are now at the top of the list. Both Pfizer-BioNTech and Moderna vaccines are made using mRNA Risk-reduction zones. Tests new items or technology in a controlled environment to determine their viability in realworld situations, determine regulatory bounds, and gauge customer and market responses the same. To reduce risk, the focus is on feedback and learning, since there exist boundaries [11]. Only four nations have regulatory sandboxes for health tech, with the bulk of them focusing on telemedicine or digital health, as of February 2020 [12].

\section{Reconciling legacy systems' fragmentation and setting the agenda}

There was a four-year study of the UK National Health Service, the most extensive civil IT program, which found that fragmentation between stakeholders increased due to the competing institutional frameworks (informal and formal values and systems) and lack of agreement on the agenda (especially how to spend money) [13]. A lack of communication between policymakers and employees on the ground contributed to this conflict and fragmentation, which hampered governance in many circumstances.

As a result of national tragedies, we have seen the health sector come to the fore. When dealing with pandemics, a more comprehensive strategy is needed (Figure 3) [14,15]. The following topics are covered: Governance and management, service delivery and research, human resources, health information systems, technology, and medicine, health funding, and citizens and vulnerable communities. Healthy societies can care for the most vulnerable and regulate communication between residents and health care experts so that they can work together for quick and early answers. An

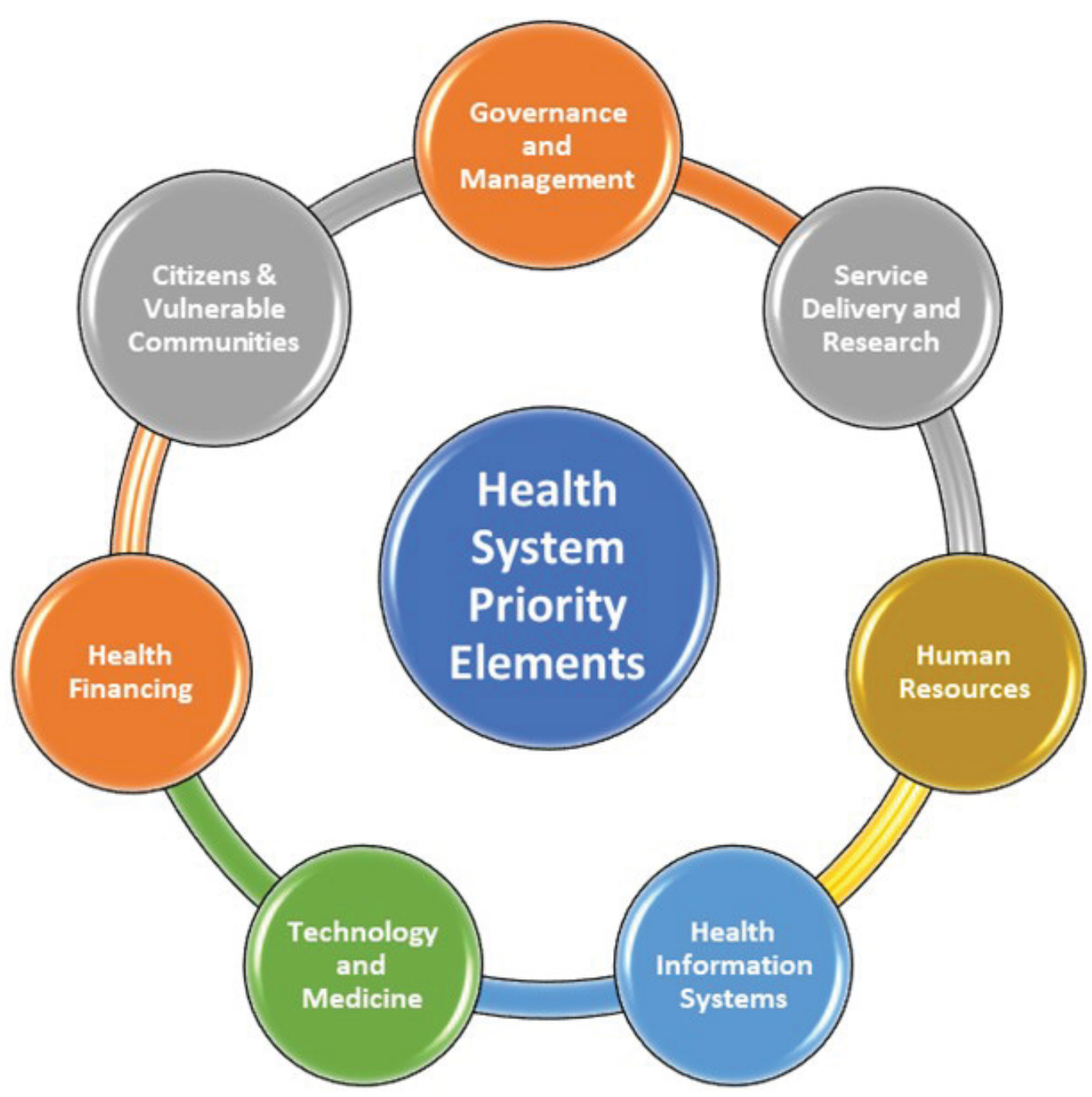

Figure 3: Managing pandemics: 7 Health system priorities [3]. 


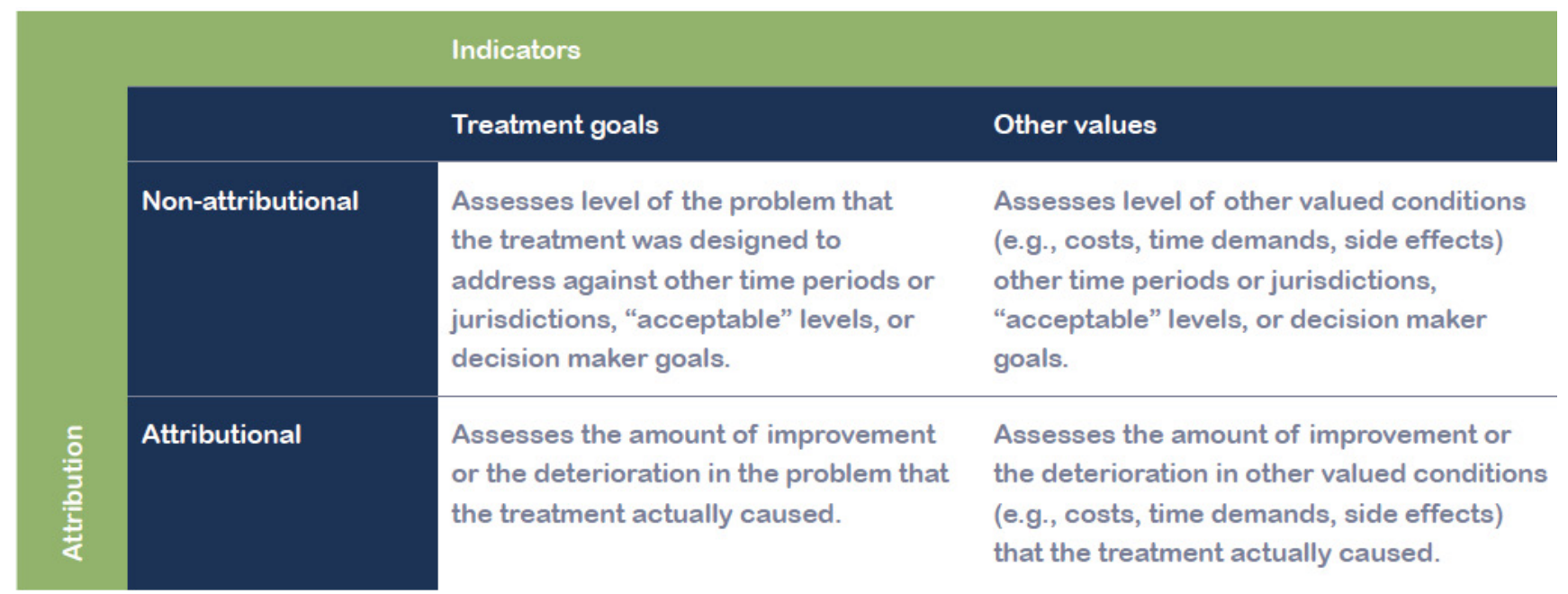

Figure 4: Outcome-based evaluation [12,23].

overview of telemedicine's participation in the epidemic, as well as the government's reaction, is provided in this article.

\section{Cross-border collaboration and interoperability of systems}

It is difficult for governments, particularly in electronic health records and e-health, to integrate historical systems. For improved health management, they need to identify the delicate line between privacy and data exchange. The big data boom is interconnected with activity claims and costs, clinical, pharmacological, and R\&D data. Many new enterprises have been created as a consequence of patient behavior and sentiment data [16]. Consumers are becoming more aware of services, which puts further pressure on the government to authorize new ones [17]. Consumers are crowdsourcing their thoughts on care providers, value for money, and new goods [17]. Governments must defend their people' health, data, and national data against cyberattacks, which are becoming more prevalent [18]. COVID-pandemic policy talks were frequently based on inadequate data sets-for example, the UK and Sweden embraced the herd immunity strategy based on earlier research of epidemics.

Estonia and Finland launched an ambitious effort in 2016 to exchange patient data in two phases: 2017-2018: cross-border access to digital prescriptions and 2018-2019: Complete patient medical history access [19]. Moving to another country for employment, vacation, school, or to reside raises the issue of data migration in general [20]. Legal framework and interoperability are needed before physicians may practice across borders, however, data exchange across borders is the first step and requires standardization of data exchange format to be reconciled on the legal framework, interoperability, and standardization of data exchange In the European Union, there is a lot of talk about electronic records sharing [21].

\section{Trade-offs in investing in upstream or downstream companies}

Upstream investments (in social determinants of health - preventative causes) may save money that has traditionally been spent downstream (on diagnosis and treatment), but evidence for policymakers has been challenging to come by [22]. As a result, it is necessary to conduct outcome-based assessments (Figure 4). Mammograms, for example, are wellknown in the field of cancer, particularly breast cancer, for their significant cost reductions. Making trade-offs, shifting resources, and reorganizing governance is necessary in order to prevent (or at least mitigate) health issues in an agile government $[23,24]$.

\section{Telemedicine's Growth}

Early experiments with video consultation in 1959 and later in crises have not been new to the notion of telemedicine. The space industry has been a significant force on the early adoption of telemedicine (instead of the telecommunication sector). There was a requirement for medical data to be accessible in early space mission voyages [25].

It was then applied to the surface of the Earth (as opposed to space). In 1971, the US government started looking at technological spinoffs to stimulate the economy, foster international cooperation, and foster interdisciplinary collaboration. In the 1985 Mexico City earthquake and the 1988 Soviet Armenia earthquake, NASA handled remote medical care. This was the beginning of telemedicine's rapid expansion. To ensure that telemedicine might develop, governments had to manage an adequate regulatory framework. It is now possible to take telemedicine to a new level thanks to mobile and wearable devices, as well as the Internet of Things (IOT). The penetration of telehealth has been somewhat modest despite recent technology breakthroughs and promises [26-30].

However, in the first four months after the launch of COVID, telehealth use has exploded over the world [26]. It is predicted that by 2026, the worldwide telemedicine industry will be worth more than $\$ 175$ billion, compared to only $\$ 45.5$ billion in 2019 [27]. Cost reductions of up to 11 percent are also a factor in the industry's development (AHA, 2015). Estimated savings of USD 3.30 for every dollar invested in telehealth program execution [28-30]. 
In contrast to the educational industry, where schools, colleges, and universities were compelled to quickly adapt to the online form of teaching, tutoring, and monitoring, the healthcare sector is still lagging behind. New laws and regulations were created or existing rules and regulations were changed to address the unexpected rise in demand for telehealth services during the COVID-19 epidemic. A wide variety of factors influenced policy, including countryspecific issues, public and professional acceptability, and infrastructural and financial arrangements. Nevertheless, one or more of the health system priorities indicated above might be met by them.

However, recent research in South Korea, the United States, the United Arab Emirates, and Norway shows that patients and healthcare service consumers prefer telemedicine services and consultations [29]. Over $84 \%$ of UAE citizens and residents were eager to explore telehealth services (according to research done by the Mohammed Bin Rashid School of Government in early 2020 (before the COVID-19 epidemic). The inclination to use teleservices was unaffected by age, gender, or country. Significant time savings, simplicity of use, and convenience were all cited as benefits of telehealth services.

\section{Telemedicine Urgency}

World Health Organization (WHO) defines telemedicine as, "the delivery of healthcare services, where distance is a critical factor, by all healthcare professionals using information and communication technologies for the exchange of valid information for diagnosis, treatment and prevention of disease and injuries, research and evaluation, and for the continuing education of healthcare providers, all in the interests of advancing the health of individuals and their communities" [30]. Telemedicine or telehealth can ensure necessary health care in these uncertain times and provide access to healthcare to more remote communities and regions. WHO recommends doctor-population ratio of $10: 10,000$, but over $40 \%$ of the WHO members have less than this number, with $26 \%$ having less than 3 [31].

Telemedicine can be leveraged to provide much-needed support and lessen the burden on the physical healthcare institutions and clinics, especially in healthcare systems' resource redistribution and optimization, following the emergency response. However, some rightfully argue that for telehealth to become a useful part of the emergency response, it first needs to become a routinely used part of the healthcare system [32]. Fortunately, there are already some good examples that exist (Figure 5).

As far back as 2000, India utilized its space resources to connect its Apollo hospital in Chittoor, Andhra Pradesh, to the Indian Space Research Organization satellites using wireless broadband technology [33]. A National Telemedicine Taskforce was established in 2005 by the Indian Ministry of Health [34]. Because of this, the private sector in India's private sector has seen a massive uptake, with institutions like Narayana Hrudayalaya, Asia Heart Foundation, and Escorts Heart Institute (cardiac care) leading the way. COVID-19, on the other hand, pushed for more aggressive telehealth rules. Telemedicine Practice Guidelines (Telemedicine Guidelines) were ultimately released on March 25, 2020 [35].

Patients in Stockholm, Sweden, were first able to get advice on getting treatment and how to manage specific disorders through a telephone service in 2003. The telephone and online service (1177 health advice) was launched in Sweden in 2013. Public health efforts to control the spread

\begin{tabular}{|c|c|c|c|c|c|c|c|c|c|c|c|c|c|}
\hline \multirow[b]{2}{*}{ Countries } & \multirow[b]{2}{*}{$\begin{array}{c}\text { 1st Confirmed COVID } \\
19 \text { case Date }\end{array}$} & \multirow[b]{2}{*}{$\begin{array}{c}\text { Tele- } \\
\text { health } \\
\text { Usage } \\
\text { during } \\
\text { COVID- } \\
19\end{array}$} & \multirow[b]{2}{*}{$\begin{array}{c}\text { Tele- } \\
\text { health } \\
\text { Regulatio } \\
\text { ns Before } \\
\text { COVID- } \\
19\end{array}$} & \multicolumn{9}{|c|}{ Telemedicine initiatives* } & \multirow{2}{*}{\begin{tabular}{|c|} 
New \\
Telemedicine \\
Policies/ \\
Process/ \\
systems \\
Introduced on \\
MOH website/
\end{tabular}} \\
\hline & & & & Telestrok & $\begin{array}{l}\text { Teleradio } \\
\text { logy }\end{array}$ & Tele-ICU & $\begin{array}{l}\text { Telement } \\
\text { al Health }\end{array}$ & $\begin{array}{l}\text { Telepath } \\
\text { ology }\end{array}$ & $\begin{array}{l}\text { Cybersur } \\
\text { gery }\end{array}$ & $\begin{array}{l}\text { Remote } \\
\text { Monitori } \\
\text { ng }\end{array}$ & $\begin{array}{l}\text { Telephar } \\
\text { macy }\end{array}$ & \begin{tabular}{|l} 
Tele- \\
Consultat \\
ions
\end{tabular} & \\
\hline China & 17th November 2019 & $\mathrm{~V}$ & $\mathrm{~V}$ & $\mathrm{~V}$ & 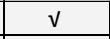 & $x$ & $x$ & 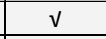 & $\sqrt{ }$ & $\sqrt{ }$ & $\sqrt{ }$ & $\sqrt{ }$ & $\mathrm{V}$ \\
\hline Thailand & 13th January 2020 & $\checkmark$ & $\mathrm{x}$ & $\mathrm{v}$ & $\mathrm{v}$ & v & $\mathrm{v}$ & $\mathrm{v}$ & $\sqrt{ }$ & 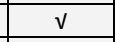 & $\sqrt{ }$ & $\checkmark$ & $\checkmark$ \\
\hline Singapore & 23rd January 2020 & $\sqrt{ }$ & $\checkmark$ & $\mathrm{v}$ & $\mathrm{v}$ & $x$ & $\mathrm{x}$ & 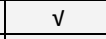 & $\checkmark$ & $\sqrt{ }$ & $\mathrm{v}$ & 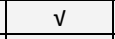 & $x$ \\
\hline Japan & 14th January 2020 & $\sqrt{ }$ & 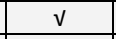 & $\mathrm{v}$ & $\mathrm{v}$ & $\sqrt{ }$ & $\mathrm{v}$ & $\mathrm{v}$ & $\sqrt{ }$ & $\mathrm{v}$ & $\sqrt{ }$ & $\sqrt{ }$ & 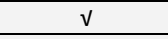 \\
\hline South Korea & 20th January 2020 & $\checkmark$ & $\mathrm{v}$ & $\mathrm{x}$ & $\mathrm{v}$ & $\checkmark$ & $\mathrm{x}$ & $x$ & $x$ & $\mathrm{v}$ & $x$ & $x$ & $x$ \\
\hline Australia & 25th January 2020 & $\sqrt{ }$ & $\mathrm{V}$ & $\mathrm{v}$ & $\sqrt{ }$ & $\sqrt{v}$ & $\mathrm{~V}$ & $\sqrt{ }$ & $x$ & $\mathrm{~V}$ & $\sqrt{ }$ & 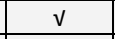 & 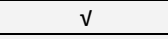 \\
\hline Spain & 31st January 2020 & $\sqrt{ }$ & $x$ & $\sqrt{ }$ & $\sqrt{ }$ & $\sqrt{ }$ & $x$ & $\sqrt{ }$ & $\mathrm{V}$ & $\sqrt{ }$ & $\mathrm{V}$ & $\checkmark$ & $x$ \\
\hline UK & 28th February 2020 & $\sqrt{ }$ & $\mathrm{v}$ & $\mathrm{v}$ & $\checkmark$ & 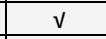 & $\mathrm{V}$ & 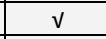 & $x$ & $\sqrt{ }$ & $\sqrt{ }$ & $x$ & $\checkmark$ \\
\hline Germany & 27th January 2020 & $\sqrt{ }$ & $\mathrm{V}$ & $\mathrm{v}$ & $\mathrm{V}$ & $\sqrt{ }$ & $\mathrm{v}$ & $\sqrt{ }$ & $\sqrt{ }$ & $\mathrm{v}$ & $\sqrt{ }$ & 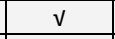 & $\sqrt{ }$ \\
\hline Canada & 25th January 2020 & $\sqrt{ }$ & $\mathrm{v}$ & $\mathrm{v}$ & $\sqrt{ }$ & $\sqrt{ }$ & $\sqrt{ }$ & $\sqrt{ }$ & $\mathrm{V}$ & $\sqrt{ }$ & $\sqrt{ }$ & $\checkmark$ & $x$ \\
\hline India & 30th January 2020 & $\checkmark$ & $x$ & 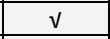 & $\sqrt{ }$ & $\mathrm{v}$ & $x$ & $\checkmark$ & $\mathrm{v}$ & 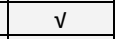 & $\checkmark$ & $\checkmark$ & $\checkmark$ \\
\hline UAE & 29th January 2020 & $\sqrt{ }$ & $\sqrt{v}$ & $x$ & $\mathrm{v}$ & $\sqrt{ }$ & $\mathrm{v}$ & $x$ & $x$ & $\mathrm{v}$ & $\mathrm{v}$ & $\sqrt{ }$ & 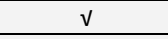 \\
\hline Iran & 19th February 2020 & $\sqrt{ }$ & $x$ & $x$ & $\mathrm{v}$ & $x$ & $\mathrm{v}$ & $x$ & $x$ & $x$ & $x$ & $\sqrt{ }$ & $x$ \\
\hline Egypt & 14th February 2020 & 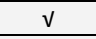 & $x$ & $x$ & $\mathrm{v}$ & $\mathrm{x}$ & $x$ & $\sqrt{ }$ & $\mathrm{x}$ & $\mathrm{x}$ & $x$ & $x$ & $x$ \\
\hline Sweden & 11th March 2020 & $\mathrm{~V}$ & 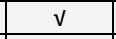 & $\mathrm{v}$ & $\mathrm{v}$ & $\mathrm{x}$ & $\mathrm{v}$ & $\sqrt{ }$ & $x$ & $x$ & $x$ & $x$ & $x$ \\
\hline Jordan & 3rd March 2020 & $\mathrm{~V}$ & $x$ & $x$ & $x$ & $\mathrm{x}$ & $x$ & $x$ & $\mathrm{x}$ & $x$ & $x$ & $\checkmark$ & $x$ \\
\hline South Africa & 1st March 2020 & 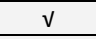 & $\mathrm{V}$ & $x$ & 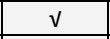 & $\mathrm{x}$ & $v$ & $x$ & $x$ & $\mathrm{x}$ & $x$ & $x$ & $\checkmark$ \\
\hline Italy & 31st January 2020 & $\sqrt{ }$ & $\mathrm{V}$ & $\mathrm{v}$ & $\mathrm{v}$ & $\mathrm{V}$ & $\mathrm{v}$ & $\mathrm{v}$ & $\mathrm{V}$ & $\mathrm{v}$ & $\sqrt{ }$ & $\sqrt{ }$ & 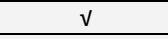 \\
\hline USA & 19th January 2020 & $\checkmark$ & $\mathrm{v}$ & $v$ & 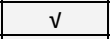 & V & $\mathrm{v}$ & $\mathrm{v}$ & $\mathrm{V}$ & $\mathrm{v}$ & $\checkmark$ & $\checkmark$ & $\checkmark$ \\
\hline France & 24th January 2020 & $v$ & $\mathrm{~V}$ & $\mathrm{~V}$ & $v$ & $x$ & $\mathrm{~V}$ & $\mathrm{~V}$ & $\mathrm{~V}$ & $v$ & $\mathrm{~V}$ & $\mathrm{~V}$ & $\mathrm{x}$ \\
\hline
\end{tabular}

Figure 5: In the age of COVID-19, telemedicine initiatives and actions. 
of COVID-19 were communicated using this well-established phone and internet channel throughout the epidemic. For patients with suspected COVID-19 symptoms, a telephone service might provide guidance and assistance without exposing them to the danger of transmission to others. This also helped relieve some of the tension on a health system that was already under a lot of pressure.

German parliament enacted the Digitale Gesundheitsanwendungen-Verordnung (DiGAV) in April 2020, which is a more complete progression in an already well-established and well-recognized telehealth service. Individuals insured by statutory health insurance are entitled to payment for particular digital health applications, which stimulates digital innovation in healthcare and eases earlier constraints. Researchers and colleges may now seek access to insurance companies' demographic and health information for research purposes, as long as the data is anonymised [36,37].

COVID-19 boosted telemedicine's acceptance and distribution. While telemedicine was permitted initially for use in the United Arab Emirates (UAE) in 2019, the implementation was hastened when COVID-19 was introduced. Existing medical liability regulations, data rules, and telecommunications infrastructure, and permissions dictated that physicians must meet patients in person before changing policy $[37,38]$. During the pandemic lockdown, patients with unmet health requirements, when most nonessential, in-person visits to hospitals or clinics were stopped, found telemedicine to be a viable option.

\section{Using telemedicine during the epidemic of COVID-19}

Governments sought to lessen the effect of COVID-19, both directly and indirectly. With the example, it seems that nations with prior experience managing legal-regulatory frameworks, ICT networks, and electronic health records may have had a leg up on their peers. Virtual consultations were illegal in Germany until 2018. Reimbursement and price for insurance providers was a major issue in a healthcare system when most of it is free. In order to address this issue, the government has established think tanks like the Health Innovation Hub (hih). A proposal for a virtual hospital was announced in Germany in August 2019 for a spring 2020 debut $[39,40]$. In March, Aachen and Münster in Germany created a virtual hospital to give immediate 24-hour consultation to more than 200 regional hospitals for critical care and infectologist treatment [40].

For established patients in South Korea, authorities approved the introduction of phone consultations and prescriptions for a short period of time. Telemedicine is forbidden in clinical practice in the nation, thus this is a big deal. As a result of significant resistance from professional organizations, particularly the Korean Medical Association, the South Korean government has lacked progress in telemedicine since the late 1990s $[40,41]$ despite having an early start in the field.

Additionally, the population's availability to technology and knowledge and comfort levels with telemedicine are important factors in telemedicine's deployment. For example, during COVID-19, Africa deployed mHealth (mobile health) for public education, self-diagnosis, contact tracking, case management, and payment. If there were no smartphones, people relied on SMS-enabled messages; if this was too difficult, they turned to radios [42]. The proliferation of COVID-19 in Africa necessitates the use of a variety of technologies. Innovative solutions are needed in circumstances when electricity and wifi are not readily accessible, which prevents cloud access in certain cases. Partnerships between the public and commercial sectors have resulted in solutions $[43,44]$.

The wearable personal Internet of Things (IOT) devices of patients and residents in nations like Taiwan, Singapore, and South Korea are used for remote monitoring of vital signs, tracking and quantification of healthcare service delivery, and health information systems [45]. In addition, comparable devices are used to monitor vital indicators (such as body temperature and respiratory symptoms) on a continuous basis, reducing the strain on healthcare workers. For governance and management purposes, business intelligence is employed during the pandemic to aid with infection control and fever monitoring. As an example, the Apple watch [46] now detects oxygen level wearables, highlighting privacy issues about citizen data in the private sector.

The COVID-19 pandemic has the potential to benefit from the utilization of current services in many nations, or they may serve as a model for future innovation, deployment, or outsourcing (Figure 6).

\section{Conclusion \& Future Directions}

There are several advantages to telehealth, including the ability to access experts and surgeons in other countries, huge cost savings, and the ability to collaborate with health care providers worldwide. Improvements to health outcomes and healthcare systems are all possible as a result of incorporating these characteristics. These innovations may also help cut down on wasteful spending and time spent providing health care. As the globe suffers with COVID-19, telehealth may be a significant and appropriate tool in the fight against illness. So, what's the point in holding off? Here are some ideas for an agile government health care sector:

1. One of the biggest obstacles to telemedicine is a lack of understanding of the legal and regulatory context. New ideas can be tested quickly in a regulatory sandbox, but they will also provide legislators with the information to improve their regulatory framework. Engage several stakeholders in an open dialogue about different topics, including ethics, governance, implementation, and trade-offs.

2. Quintuple Helix. By establishing high-level think tanks that include representatives from government, commercial sector, non-profits, and civil service groups, and academics. The goal is to get an understanding of how government, public value, the private sector, and environmental issues all contribute to a company's bottom line. 
Figure 6: COVID-19 pandemic management: Telemedicine platforms.

\begin{tabular}{|c|c|c|}
\hline Platform & Description & Country (Examples) \\
\hline Telestroke [47] & $\begin{array}{l}\text { Remote evaluations, diagnoses, and treatment recommendations } \\
\text { are transmitted to emergency medicine doctors at other sites } \\
\text { using advanced telecommunications technologies. }\end{array}$ & $\begin{array}{l}\text { China (National Telestroke Center) } \\
\text { Italy } \\
\text { Singapore } \\
\text { Thailand } \\
\text { USA (AllinaHealth) }\end{array}$ \\
\hline $\begin{array}{l}\text { Teleradiology } \\
\text { [48] }\end{array}$ & $\begin{array}{l}\text { Images and associated data are transmitted between locations for } \\
\text { primary interpretation or consultation and clinical review. }\end{array}$ & $\begin{array}{l}\text { Australia } \\
\text { Egypt } \\
\text { Germany } \\
\text { Spain } \\
\text { South Africa } \\
\text { USA (USARAD) }\end{array}$ \\
\hline Tele-ICU [49] & $\begin{array}{l}\text { Networks of audio-visual communication and computer systems } \\
\text { are linked with critical care physicians and nurses to ICUs in other, } \\
\text { often remote hospitals. }\end{array}$ & $\begin{array}{l}\text { Canada } \\
\text { Egypt (Phillips) } \\
\text { India } \\
\text { United Arab Emirates }\end{array}$ \\
\hline Telemental Health [50] & $\begin{array}{l}\text { Mental health and substance abuse services are provided from } \\
\text { a distance (e.g., using videoconferencing and other advanced } \\
\text { communication technologies). }\end{array}$ & $\begin{array}{l}\text { France } \\
\text { Japan } \\
\text { United Arab Emirates (Dubai Health } \\
\text { Authority; Ministry of Health \& Prevention) } \\
\text { United Kingdom }\end{array}$ \\
\hline Telepathology [51] & $\begin{array}{l}\text { The pathology practice is performed at a remote location utilizing } \\
\text { video cameras, monitors, and a remote-controlled microscope. }\end{array}$ & $\begin{array}{l}\text { China } \\
\text { India } \\
\text { Singapore } \\
\text { Thailand } \\
\text { USA (LabPulse) }\end{array}$ \\
\hline Cybersurgery [52] & $\begin{array}{l}\text { Surgeons use surgical techniques with a telecommunication } \\
\text { conduit connected to a remote patient's robotic instrument. }\end{array}$ & $\begin{array}{l}\text { Canada } \\
\text { China } \\
\text { France } \\
\text { Germany } \\
\text { Italy } \\
\text { Spain (Cyber Surgery) }\end{array}$ \\
\hline $\begin{array}{l}\text { Remote } \quad \text { Monitoring } \\
{[53,54]}\end{array}$ & $\begin{array}{l}\text { Patients are subject to continuous or frequent periodic clinical } \\
\text { monitoring via advanced communication technologies. }\end{array}$ & $\begin{array}{l}\text { France } \\
\text { Spain } \\
\text { South Korea, } \\
\text { Taiwan (LCG Memorial Hospital) } \\
\text { USA }\end{array}$ \\
\hline Telepharmacy [55] & $\begin{array}{l}\text { Pharmaceutical care for patients (or supervision to technicians) } \\
\text { is provided at a distance using advanced telecommunications } \\
\text { technology. }\end{array}$ & $\begin{array}{l}\text { Australia } \\
\text { Canada (College of Pharmacists of British } \\
\text { Columbia) } \\
\text { Japan } \\
\text { Spain }\end{array}$ \\
\hline
\end{tabular}




\begin{tabular}{|l|l|l|} 
Tele-Consultation [55] & $\begin{array}{l}\text { Remote consults are conducted with remote specialists, primary } \\
\text { care providers, counselors, social workers, and other health care } \\
\text { professionals. }\end{array}$ & France \\
& Germany (Virtual hospitals) \\
Japan & Jordan \\
& Singapore \\
& Thailand \\
& United Arab Emirates \\
& (Dubai Health Authority; Ministry of Health \\
\& Prevention) & USA
\end{tabular}

3. In order to have a successful m-health or telehealth system, the infrastructure must include electricity and ICT technologies as well as data management and telehealth equipment. Developing policies that take into account both current and emergencies are essential.

4. With the rise of Big Data and Al, data ownership is becoming the next battleground between and between countries. Even though the German government urges residents to "give" their data [56,57], it is unclear where the authorization limits are in other circumstances. An agile government relies heavily on trust, and the rules and enforcement of the same must be crystal clear. In order to keep up with population movement as paperbased records are phased out, we must coordinate data transmission across borders (data mobility).

5. Until sufficient investment has been made upstream to provide maximum coverage, governments must engage with healthcare providers, insurance companies, and other government players in order to control health expenses for the ultimate consumer.

\section{Funding}

The authors disclose receipt of the following financial support for the authorship, research, and/or publication of this article: The authors would like to acknowledge Mohammed Bin Rashid School of Government (MBRSG), Dubai, UAE, and the Alliance for Health Policy and Systems Research at the World Health Organization for financial support as part of the Knowledge to Policy (K2P) Center Mentorship Program [BIRD Project].

\section{Acknowledgements}

We want to acknowledge Mohammed Bin Rashid School of Government, Dubai, UAE, and the Alliance for Health Policy and Systems Research for financial support at the World Health Organization as part of the Knowledge to Policy (K2P) Center Mentorship Program [BIRD Project].

\section{Competing interests}

We have no conflicting or competing interests.

\section{References}

1. World Health Organization (2021) Coronavirus disease (COVID-19) situation report.

2. World Health Organization (2018) WHO Guide on managing epidemics.

3. AlQutob R, Ajlouni MT, Abufaraj M, et al. (2020) Jordan's public and surveillance health policies: During and after COVID-19. Jordan Journal of Pharmaceutical Sciences 13: 1-12.

4. BBC (2020) Coronavirus: The world in lockdown in maps and charts.

5. World Health Organization (2020) Coronavirus disease (COVID-19) technical guidance: Maintaining essential health services and systems.

6. World Health Organization (2020) Pulse survey on continuity of essential health services during the COVID-19 pandemic: Interim report.

7. American Hospital Association (2020) Hospitals and health systems face unprecedented financial pressures due to COVID-19.

8. Mc Dermott D, Ox C (2020) What impact has the coronavirus pandemic had on healthcare employment?

9. Chen M, Fang G, Wang L, et al. (2015) Who benefits from government healthcare subsidies? An assessment of the equity of healthcare benefits distribution in China. PLoS One 10: e0119840.

10. Garde D, Saltzman J (2020) The story of mRNA: How a oncedismissed idea became a leading technology in the Covid vaccine race. Boston Globe.

11. Stephens M, Moonesar IA (2021) How do intergovernmental organizations embed themselves in global value chains: A case study of Gavi, the Vaccine Alliance. International Entrepreneurship Review 7: 7-21.

12. Al Hajaj K, Stephens M (2020) Regulatory sandbox: Health reglab design elements. UAE PPF report. Mohammed Bin Rashid School of Government, Dubai.

13. Currie WL, Guah MW (2007) Conflicting institutional logics: A national programme for IT in the organisational field of healthcare. J Inf Technol 22: 235-247.

14. AlQutob R, Moonesar IA, Tarawneh MR, et al. (2020) Public health strategies for a gradual public sector lockdown lifting in Jordan and United Arab Emirates during COVID-19 crisis. JMIR Public Health Surveill 6: e20478. 
15. Ines M, Gong Y, Bertot J (2018) Agile government: Systematic literature review and future research. Government Information Quarterly 35: 291-298.

16. Sindhwani R, Singh PL, Prajapati DK, et al. (2019) Agile system in health care: Literature review. In: Advances in Industrial and Production Engineering, Springer, Singapore, 643-652.

17. Groves P, Kayyali B, Knott D, et al. (2013) The big data revolution in healthcare: Accelerating value and innovation. McKinsey \& Company.

18. Atherley G (2005) Evidence of public value and public risk of electronic health records: An issue for social justice? Electronic Healthcare 4: 96-103.

19. Estonia E (2016) Estonia and Finland to start sharing patient data. And that's just the start!

20. Michalopolous S (2018) Estonia and Finland first to start exchanging healthcare data by end of year. Euractiv.

21. European Commission (2020) Exchange of electronic health records across the EU.

22. Bogdańska K (2018) Health care's 'upstream' conundrum, Politico.

23. Coglianese $C$ (2012) Measuring regulatory performance. OECD.

24. Syrett K (2018) Doing 'Upstream' priority-setting for global health with Justice: Moving from vision to practice? Public Health Ethics 11: 265-274.

25. (2013) A brief history of NASA's contributions to telemedicine. NASA.

26. Chellaiyan VG, Nirupama AY, Taneja N (2019) Telemedicine in India: Where do we stand? J Family Med Prim Care 8: 1872-1876.

27. Moonesar IA, Hussain M, Gaafar R, et al. (2020) Rapid response: Informing United Arab Emirates' response to the COVID-19 pandemic. Mohammed Bin Rashid School of Government, Dubai, United Arab Emirates.

28. Latifi R, Doarn CR (2020) Perspective on COVID-19: Finally, telemedicine at center stage. Telemedicine and e-Health 26: 9.

29. Smith AC, Thomas E, Snoswell CL, et al. (2020) Telehealth for global emergencies: Implications for coronavirus disease 2019 (COVID-19). J Telemed Telecare 26: 309-313.

30. Statista (2020) Global telemedicine market size in 2019 and a forecast for 2030.

31. American Hospital Association (2015) The promise of telehealth for hospitals, health systems and their communities, Trend Watch.

32. Moonesar IA, Dass R (2021) Artificial intelligence in health policy-A global perspective. Global Journal of Computer Science and Technology 21: 1-8.
33. WHO (2010) Telemedicine-Opportunities and developments in member states. ( $2^{\text {nd }}$ edn), Geneva, Switzerland, WHO press.

34. WHO (2021) Medical doctors (per 10000 population).

35. ISRO Telemedicine Initiative. Televital.com.

36. Arogya Legal (2020) India's new Telemedicine Practice Guidelines - Analysis and Do's and Don'ts for Doctors offering teleconsultation.

37. Al Tamimi (2019) DHA Issues new standard for Telehealth Services.

38. Gerke S, Stern AD, Minssen T (2020) Germany's digital health reforms in the COVID-19 era: Lessons and opportunities for other countries. NPJ digital medicine 3: 1-6.

39. Olesch A (2020) Germany benefits from digital health infrastructure during COVID-19 pandemic. HIMSS.

40. MTRC (2019) The plans for the digital platform "Virtual Hospital" presented in Germany.

41. EIT (2020) The University Hospital RWTH Aachen participates in the Virtual Hospital North Rhine-Westphalia.

42. Peine A, Paffenholz P, Martin L, et al. (2020) Telemedicine in Germany during the COVID-19 Pandemic: Multi-professional national survey. J Med Internet Res 22: e19745.

43. Nachega JB, Leisegang R, Kallay O, et al. (2020) Mobile health technology for enhancing the COVID-19 response in Africa: A potential game changer? Am J Trop Med Hyg 103: 3-5.

44. Harrisberg K (2020) Here's how Africans are using tech to combat the coronavirus pandemic. WEF.

45. Sheikhdon Y (2020) In Somalia, innovation is key to revolutionizing health care. World Bank Blogs.

46. Lee $Y$ (2020) Covid-19: Taiwan's new 'electronic fence' for quarantines leads wave of virus monitoring.

47. Macon Cooney B, Dace H, Rolnik B (2020) Wearables, Covid-19 and the health-tech revolution. Tony Blair Institute for Global Change.

48. More on telestroke.

49. More on teleradiology.

50. More on Tele-ICU.

51. More on telemental health.

52. More on telepathology.

53. More on cybersurgery.

54. More on remote monitoring.

55. More on telepharmacy.

56. More on tele-consultations.

57. More on corona-datenspende App.

DOI: $10.36959 / 569 / 472$

Copyright: (C) 2022 Moonesar IA. et al This is an open-access article distributed under the terms of the Creative Commons Attribution License, which permits unrestricted use, distribution, and reproduction in any medium, provided the original author and source are credited. 